\title{
A novel expression platform for the production of diabetes-associated autoantigen human glutamic acid decarboxylase (hGAD65) \\ Xiaofeng Wang1, Martin Brandsma ${ }^{1}$, Reynald Tremblay ${ }^{1}$, Denis Maxwell ${ }^{1,4}$, Anthony M Jevnikar ${ }^{2,3}$, Norm Huner ${ }^{1,4}$ and Shengwu Ma*1,2,3
}

\begin{abstract}
Address: ${ }^{1}$ Department of Biology, University of Western Ontario, London, Ontario, N6A 5B7, Canada , 2 Transplantation Immunology Group,

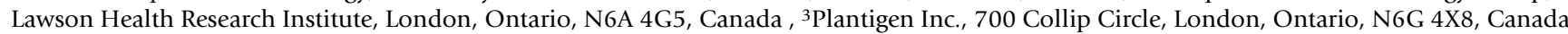
and ${ }^{4}$ The Biotron Centre for Experimental Climate Change, The University of Western Ontario, 1151 Richmond Street N., Ste. 5150 SSB, London, Ontario, N6A 3K7, Canada

Email: Xiaofeng Wang - xwang244@uwo.ca; Martin Brandsma - mbrandsm@uwo.ca; Reynald Tremblay - rtremb2@uwo.ca;

Denis Maxwell - dmaxwell@uwo.ca; Anthony M Jevnikar - jevnikar@uwo.ca; Norm Huner - nhuner@uwo.ca; Shengwu Ma* - sma@uwo.ca

* Corresponding author
\end{abstract}

Published: 17 November 2008

BMC Biotechnology 2008, 8:87 doi:10.1 186/1472-6750-8-87
Received: 30 May 2008

Accepted: 17 November 2008

This article is available from: http://www.biomedcentral.com/1472-6750/8/87

(C) 2008 Wang et al; licensee BioMed Central Ltd.

This is an Open Access article distributed under the terms of the Creative Commons Attribution License (http://creativecommons.org/licenses/by/2.0), which permits unrestricted use, distribution, and reproduction in any medium, provided the original work is properly cited.

\begin{abstract}
Background: Human glutamic acid decarboxylase 65 (hGAD65) is a key autoantigen in type I diabetes, having much potential as an important marker for the prediction and diagnosis of type I diabetes, and for the development of novel antigen-specific therapies for the treatment of type I diabetes. However, recombinant production of hGAD65 using conventional bacterial or mammalian cell culture-based expression systems or nuclear transformed plants is limited by low yield and low efficiency. Chloroplast transformation of the unicellular eukaryotic alga Chlamydomonas reinhardtii may offer a potential solution.
\end{abstract}

Results: A DNA cassette encoding full-length hGAD65, under the control of the $C$. reinhardtii chloroplast rbcL promoter and 5'- and 3'-UTRs, was constructed and introduced into the chloroplast genome of $C$. reinhardtii by particle bombardment. Integration of $h$ GAD65 DNA into the algal chloroplast genome was confirmed by PCR. Transcriptional expression of $h G A D 65$ was demonstrated by RT-PCR. Immunoblotting verified the expression and accumulation of the recombinant protein. The antigenicity of algal-derived hGAD65 was demonstrated with its immunoreactivity to diabetic sera by ELISA and by its ability to induce proliferation of spleen cells from NOD mice. Recombinant hGAD65 accumulated in transgenic algae, accounts for approximately $0.25-0.3 \%$ of its total soluble protein.

Conclusion: Our results demonstrate the potential value of $C$. reinhardtii chloroplasts as a novel platform for rapid mass production of immunologically active hGAD65. This demonstration opens the future possibility for using algal chloroplasts as novel bioreactors for the production of many other biologically active mammalian therapeutic proteins. 


\section{Background}

In recent years, there has been increased interest in using genetically engineered plants as an alternative expression system for the production of recombinant pharmaceutical proteins [1,2]. Plant systems offer advantages over conventional expression platforms in a number of areas, including low production cost, easy and quick scale-up, low risk of product contamination by mammalian viruses or blood-borne pathogens, and an overall higher quality of products. To date, nuclear transformed plants have been shown to be able to produce numerous recombinant proteins of therapeutic value, including human diagnostic and therapeutic full-length and single-chain antibodies, antigens, cytokines and autoantigens. Moreover, crop plants can be used for the production and delivery of safe and effective edible vaccines against various infectious and immune-related diseases (For more information, see recent reviews by $\mathrm{Ma}$ et al. [3,4]. Despite this promise, nuclear transformed transgenic plants often yield relatively low levels of recombinant protein. For example, the nuclear expression of hepatitis B virus (HBV) envelop surface protein in transgenic tobacco plants was reported as $0.01 \%$ of total soluble protein (TSP) [5], whereas the accumulation level of cholera toxin B subunit (CTB), a vaccine antigen against cholera, in nuclear transgenic tobacco was between 0.02 to $0.1 \%$ of TSP $[6,7]$. Therefore, new strategies need to be developed to overcome limited recombinant protein accumulation before the potential of transgenic plants for therapeutic protein production can be fully realized.

An alternative strategy for improving foreign protein production yield is through chloroplast transformation of higher plants or closely related eukaryotic green algae. Evidence suggests that use of transgenic chloroplasts as bioreactors offers significant advantages over nuclear transformed plants. These include high-level protein accumulation due to increased foreign gene content in chloroplasts (up to 10,000 copies/leaf cell in tobacco; or 80 copies/cell in Chlamydomonas reinhardtii), expression of multiple genes through a single transformation event, increased transgene containment because of maternal plastid inheritance, as well as a lack of position effects on foreign genes [8]. Additionally, the endogenous presence of chloroplast chaperones and enzymes aids in complex multi-subunit protein assembly and can correctly fold proteins containing disulfide bonds, thereby drastically reducing the costs of in vitro processing. High levels of foreign proteins have been obtained via expression through the chloroplast genome. For example, the expression level of CTB in chloroplast transgenic plants reached up to $4.1 \%$ of TSP [9], while its expression level in nuclear transgenic plants accounted for 0.02 to $0.1 \%$ of TSP $[6,7]$. Similarly, while the expression level of human serum albumin, an important therapeutic protein with many applications, in nuclear transgenic plants was around $0.2 \%$ of TSP [10], expression levels of up to $11.2 \%$ of TSP were observed in chloroplast transgenic plants [11]. There are many other vaccine antigens or biopharmaceutical proteins that have been produced in chloroplast transgenic plants. They include, for example, Bacillus anthracis protective antigen (PA) against anthrax [12,13], fragment $\mathrm{C}$ of tetanus toxin (TetC) for tetanus [14], the outer surface protein A (OspA) of Borrelia burgdorferi against Lyme disease [15] and cytokines such as interferon $\alpha 2 b$ (IFN $\alpha 2 b)$ and IFN- $\gamma[16,17]$ as well as a diabetes-associated autoantigen human proinsulin [18]. Furthermore, many of them have been shown to be fully functional in animal studies. The reader is referred to the recent reviews by Daniell and colleagues for further information $[8,19,20]$.

Compared to chloroplast transgenic plants, the use of chloroplast transgenic algae as a bioreactor offers several additional advantages. Microalgae, such as C. reinhardtii, grow and reproduce faster than any other terrestrial or aquatic plant, doubling its biomass in approximately 8 hour, and microalgae are non-toxic and non-polluting, thus environmentally friendly for mass cultivation and commercial exploitation. Also, there will be a significant reduction in the time required to generate transgenic algae as compared to higher plants. In general, stable transplastomic lines can be obtained in as little as 3 weeks, with the potential to scale up to mass production in an additional 4-6 weeks [21]. All of these have made microalgal chloroplasts to be another valuable platform for the molecular farming of pharmaceutical proteins. Indeed, the C. reinhardtii chloroplast expression of a large single-chain antibody has shown accumulation levels of 0.5 to $1 \%$ of algal TSP [22]. Recently, Manuell et al. [23] demonstrated robust expression of a bioactive mammalian peptide, bovine mammary-associated serum amyloid (M-SAA), in C. reinhardtii chloroplasts with levels up to 5\% of TSP. There are several other antigenic proteins that have been produced using this system, including foot-and-mouth disease virus VP1 protein [24], tumor necrosis factorrelated apoptosis-inducing ligand (TRAIL) [25] and the protein E2 of classical swine fever virus [26]. The reader is referred to recent reviews on this area for further information $[21,27]$.

Glutamic acid decarboxylase-65 (GAD65) catalyzes the formation of gamma-aminobutyric acid (GABA) from glutamine. It is one of the major autoantigens in type 1 (insulin-dependent) diabetes, an autoimmune disease resulting from the destruction of insulin-producing $\beta$ cells in the pancreas $[28,29]$. It has been demonstrated that many new-onset type 1 diabetic patients have autoantibodies against GAD65, with the presence of anti-GAD65 antibodies now serving as an important marker for the 
prediction and diagnosis of type 1 diabetes [30-32]. The identification of GAD as a major autoantigen in type 1 diabetes may also present unique opportunities for the development of novel preventative therapies against the disease. Indeed, immunization of young non-obese diabetic (NOD) mice, an animal model for human type 1 diabetes, with GAD65 or GAD peptides prevents or delays the onset of diabetes [33-35]. Furthermore, the suppression of GAD in NOD mouse islets was shown to protect the mice from developing diabetes [36]. All of these results suggest the potential importance of GAD65 in diagnosing and treating type 1 diabetes in humans. However, recombinant production of hGAD65 using conventional bacterial or mammalian cell culture-based expression systems is limited by high cost, low efficiency and low yield. To overcome these limitations, we have recently explored transgenic plants as an alternative expression platform for the production of hGAD65 [37]. Although transgenic plants offer several production advantages, including the possibility of allowing direct oral delivery of plant-derived GAD65 to induce oral immune tolerance, plant expression of hGAD65 is still limited by low accumulation levels $(0.04 \%$ of TSP in tobacco).

The goal of the present study was to investigate the feasibility of using C. reinhardtii chloroplasts as a novel expression platform for the production of hGAD65. To this end, a chloroplast transformation vector containing the fulllength $h \mathrm{GAD} 65$ gene, under the control of the C. reinhardtii chloroplast $r b c \mathrm{~L}$ promoter as well as $r b c \mathrm{~L} 5$ '- and 3'UTRs, was generated and introduced into the chloroplast genome of $C$. reinhardtii. Here, we show that chloroplast transformed $C$. reinhardtii cells express and accumulate recombinant hGAD65 at levels of $0.25-0.3 \%$ of algal TSP. Immunological analysis shows algal-derived recombinant hGAD65 reacts with Type 1 diabetic sera from NOD mice, and stimulates the proliferation of spleen lymphocytes from NOD mice. These results demonstrate that agal-derived GAD65 contains its authentic antigenicity, further suggesting the potential use for microalgae as a novel production system for human therapeutic proteins.

\section{Methods}

\section{Strains, growth media and culture conditions}

C. reinhardtii wild-type strain $137 \mathrm{c}$ was used as a host for chloroplast transformation. Cells of the strain 137c were maintained on Tris Acetate Phosphate (TAP) agar or grown in liquid TAP medium at $23^{\circ} \mathrm{C}$ under constant illumination of $\sim 100 \mu \mathrm{E} / \mathrm{m}^{2} \cdot \mathrm{sec}^{-1}$. When grown in TAP liquid medium, algal cells were cultured in flasks rotating at 100 rpm.

\section{Construction of the chloroplast expression vector $p X W$ - GAD-His}

To construct chloroplast expression vector pXW-GAD65-6 $\times$ His, $h$ GAD 65 cDNA was amplified by PCR from plasmid vector pTRL-GAD65 [37] using the primer pairs: 5'- TTCCATGGCATCTCCGGGCTCTGGC-3' (forward) and 5'ATAATCTAGATTAATGATGATGATGATGATGTAAATCTT-

GTCCAAGGCG TTC-3' (reverse). The forward primer contains an engineered $\mathrm{NcoI}$ site (underlined), whereas the reverse primer contains an $\mathrm{XbaI}$ site (underlined) immediately downstream of sequence encoding the $6 \times$ His-tag (italic) and stop codon (bold). PCR was performed on a Perkin-Elmer Model 9600 thermocycler under the following conditions: initial denaturation for $5 \mathrm{~min}$ at $94^{\circ} \mathrm{C}$, followed by 30 cycles of denaturation at $94^{\circ} \mathrm{C}$ for $30 \mathrm{~s}$, annealing at $50^{\circ} \mathrm{C}$ for $30 \mathrm{~s}$, and extension at $72^{\circ} \mathrm{C}$ for 60 $\mathrm{s}$, followed by a final extension of $10 \mathrm{~min}$ at $72^{\circ} \mathrm{C}$. The PCR product was isolated and blunt-end ligated into the SmaI site of pUC19. After verification by sequence analysis, the hGAD65 gene was released by digestion with $\mathrm{NcoI}$ and $\mathrm{XbaI}$, blunt-ended with Klenow fragment, and cloned into Chlamydomonas chloroplast transformation vector pUC7-463, composed of the $r b c \mathrm{~L}$ gene promoter and its $5^{\prime}$ untranslated region (5' UTR) and 3' UTR. The resulting hGAD65 expression cassette was then isolated as a single $B a m \mathrm{HI}$ fragment and ligated into the $C$. reinhardtii chloroplast transformation vector $\mathrm{p} 322$, containing the $5.7 \mathrm{~kb}$ EcoRI/XhoI restriction fragment from the C. reinhardtii inverted repeat region (Chlamydomonas Stock Center), forming plasmid pXW-GAD-His.

\section{Chloroplast tranformation}

C. reinhardtii wild type strain $137 \mathrm{c}$ was grown in TAP liquid medium to late log phase (approximately 7 days), with subsequent cell harvesting by centrifugation $(2060 \mathrm{~g}$ for 10 minutes at $4{ }^{\circ} \mathrm{C}$ ). The cell pellet was resuspended in TAP to a density of approximately $1.0 \times 10^{8}$ cells $/ \mathrm{mL}$. Of this cell suspension, $250 \mu \mathrm{l}$ was spotted onto the central area $(1.5 \mathrm{~cm}$ in diameter) of a TAP agar plate and incubated in the dark at room temperature for 2 hours. After incubation, plates were bombarded with $5 \mu \mathrm{g}$ of pXWGAD-His DNA mixed with equal amounts of plasmid p228 DNA and coated onto tungsten particles for delivery using a Biolistic PDS-1000/He Particle Delivery System (Bio-Rad Laboratories) as described by Boynton et al. [38]. Plasmid p228, containing the 165 rRNA gene conferring spectinomycin resistance, was used to screen and/or identify transformed algal cells. Bombarded cells were incubated overnight in the dark at room temperature, replated onto TAP agar plates containing spectinomycin $(150 \mu \mathrm{g} / \mathrm{mL})$ and incubated under dim light. Colonies appearing after 2-3 weeks were re-streaked onto TAP agar plates containing spectinomycin and grown for approximately one more week. Colony cells were subcultured into TAP liquid medium containing $50 \mu \mathrm{g} / \mathrm{ml}$ spectino- 
mycin and grown for one day under shaking conditions. Cells were then diluted and plated onto TAP agar plates containing spectinomycin to obtain single colonies. Several rounds of replating on selective medium were required to obtain homoplasmic cell lines.

\section{DNA isolation and PCR analysis}

Total DNA was isolated from wild-type C. reinhardtii and transformants using the method described by Newman et al. [39] with minor modifications. Briefly, cells were grown in liquid TAP medium, harvested by centrifugation $\left(2000 \times \mathrm{g}\right.$ for $10 \mathrm{~min}$ at $\left.4^{\circ} \mathrm{C}\right)$ and resuspended in TEN buffer (10 mM Tris-HCl, $10 \mathrm{mM}$ EDTA, $150 \mathrm{mM} \mathrm{NaCl}, \mathrm{pH}$ 8.0). The cell suspension was centrifuged, and the pellet resuspended in $150 \mu \mathrm{H} \mathrm{H}_{2} \mathrm{O}$ on ice and to it, $300 \mu \mathrm{l}$ of SDSEB buffer (2\% SDS, $400 \mathrm{mM} \mathrm{NaCl}, 40 \mathrm{mM}$ EDTA, 100 $\mathrm{mM}$ Tris- $\mathrm{HCl}, \mathrm{pH}$ 8.0) was added. The suspension was extracted once with $350 \mu \mathrm{l}$ of phenol/CIA (25:24:1 by volume, phenol:chloroform:isoamyl alcohol) and the aqueous phase was collected and added with $300 \mu$ l of CIA. After a final centrifugation, the aqueous phase was collected, mixed with two volumes of $100 \%$ ethanol and incubated on ice for 30 minutes. The solution was centrifuged at $12,000 \times \mathrm{g}$ for 10 minutes to pellet the DNA. The DNA was then subjected to PCR analysis. To confirm the presence of the $h G A D 65$ gene, PCR was performed using the following pair of $h G A D 65$ specific primers: forward 5'AAGAATTCTGGCATCTCCGGGCTCTG-3' (GAD-1), and reverse 5'- AATTCTCGAGTTATAAATCTTGTCCAAGGCG3 ' (GAD-2). PCR reaction conditions were as follows: initial denaturation at $94^{\circ} \mathrm{C}$ for $5 \mathrm{~min}$, followed by 35 cycles of denaturation at $94^{\circ} \mathrm{C}$ for $1 \mathrm{~min}$, annealing at $50^{\circ} \mathrm{C}$ for $30 \mathrm{~s}$, and extension at $72^{\circ} \mathrm{C}$ for $60 \mathrm{~s}$, followed by a final extension of $10 \mathrm{~min}$ at $72^{\circ} \mathrm{C}$. To determine the specific integration site of GAD 65 in the chloroplast genome, long range PCR was performed using the long PCR enzyme mix (Fermentas, Glen Burnie, MD) with primer sets $\mathrm{CP} 3$, GAD-1 and CP4, GAD-2. The primer CP3 (5'-CCGTTCGTGCTGTGCTAGACAG-3') represents a location at one end of the inverted region of the chloroplast genome in $C$. reinhardtii, whereas the primer CP4 (5'-CGAATAACTGGGTGAATTGTCAGG-3') represents a location at the other end of this inverted region (Figure 1). PCR reaction conditions were as follows: initial denaturation at $94^{\circ} \mathrm{C}$ for $2 \mathrm{~min}, 10$ cycles of $20 \mathrm{~s}$ each at $94^{\circ} \mathrm{C}, 30 \mathrm{~s}$ at $59^{\circ} \mathrm{C}$ and $4 \mathrm{~min}$ at $68^{\circ} \mathrm{C}$ followed by 25 cycles of $20 \mathrm{~s}$ each at $94^{\circ} \mathrm{C}$, $30 \mathrm{~s}$ at $59^{\circ} \mathrm{C}$ and $4 \mathrm{~min}$ and $2 \mathrm{~s}$ at $68^{\circ} \mathrm{C}$. To identify homoplasmic cell lines, PCR was performed with chloroplast specific primers CP3 and CP4 using the following reaction conditions: initial denaturation at $94^{\circ} \mathrm{C}$ for $5 \mathrm{~min}, 10$ cycles of $20 \mathrm{~s}$ each at $94^{\circ} \mathrm{C}, 30 \mathrm{~s}$ at $57^{\circ} \mathrm{C}$ and $7 \mathrm{~min}$ at $68^{\circ} \mathrm{C}$, and followed by 25 cycles of $20 \mathrm{~s}$ each at $94^{\circ} \mathrm{C}, 30$ $\mathrm{s}$ at $57^{\circ} \mathrm{C}$ and $7 \mathrm{~min}$ and $5 \mathrm{~s}$ at $68^{\circ} \mathrm{C}$. PCR products were analysed by agarose gel electrophoresis.

\section{RNA isolation and RT-PCR analysis}

Total RNA was extracted from wild-type C. reinhardtii and transformants using the TRIzol RNA extraction kit according to the manufacturer's instructions. RNA was reverse transcribed to cDNA by SuperScript II Reverse Transcriptase (Invitrogen) according to the manufacturer's protocol. Briefly, $5 \mu \mathrm{g}$ of total RNA, $1 \mu \mathrm{l}$ Oligo(dT) $)_{12-18}$ $(500 \mu \mathrm{g} / \mathrm{ml}), 1 \mu \mathrm{ldNTP}$ Mix $(10 \mathrm{mM}$ each $)$ and $5 \mu \mathrm{l}$ sterile distilled water were mixed and incubated at $65^{\circ} \mathrm{C}$ for 5 min. Following addition of $4 \mu$ l First-Strand Buffer and 2 $\mu \mathrm{l} 0.1 \mathrm{M}$ DTT, the reaction mixture was further incubated for $2 \mathrm{~min}$ at $42^{\circ} \mathrm{C}$. After incubation, $1 \mu \mathrm{l}$ of SuperScript ${ }^{\mathrm{TM}}$ II Reverse Transcriptase was added and incubated at $42^{\circ} \mathrm{C}$ for $50 \mathrm{~min}$. The resulting cDNA was used as template for PCR, using hGAD65 specific primers. PCR reactions contained $2 \mu \mathrm{l}$ of cDNA, $0.2 \mathrm{mM}$ dNTPs, $2 \mu \mathrm{M}$ of each primer, $1 \times$ reaction buffer, $1.5 \mathrm{mM} \mathrm{MgCl}_{2}$, and $2.5 \mathrm{U}$ of Taq polymerase in a total volume of $50 \mu \mathrm{l}$. These reactions were incubated at $95^{\circ} \mathrm{C}$ for $5 \mathrm{~min}$, followed by 30 cycles of $94^{\circ} \mathrm{C}$ for $1 \mathrm{~min}, 50^{\circ} \mathrm{C}$ for $1 \mathrm{~min}, 72^{\circ} \mathrm{C}$ for $2 \mathrm{~min}$ with a final extension of $10 \mathrm{~min}$ at $72^{\circ} \mathrm{C}$. The PCR products were ran on a $1.5 \%$ agarose gel and compared against a DNA ladder (Life Technologies, Grand Island, NY).

\section{Western Blot analysis}

Total crude protein was extracted from transformants and wild-type C. reinhardtii using the method as described by Goldschmidt-Clermont [40]. For immunoblot analysis, protein extract was boiled, separated on a 15\% SDS polyacrylamide gel and blotted onto PVDF (polyvinylidene difluoride) membrane (Millipore, Burlington, MA). Membranes were blocked in 5\% skim milk-TBST(20 mM Tris, $150 \mathrm{mM} \mathrm{NaCl}, 0.02 \%$ Tween 20, pH 7.6), washed with TBST, and then incubated for $1 \mathrm{~h}$ with a 1:2000 dilution of a rabbit anti-GAD65/67 primary antibody (SigmaAldrich Canada, Oakville, Ontario) followed by incubation with 1:2500 diluted horseradish peroxidase conjugated goat anti-rabbit secondary antibody. Immunodetection was performed using the enhanced chemiluminescence (ECL) detection system (Perkin Elmer Life Sciences, Rockford, IL) according to the manufacturer's instructions. Quantification of the expression level of hGAD65 in algal cells was performed by a sandwich ELISA. In brief, a 96-well microtiter plate was coated with mouse anti-GAD65 (Abcam, Cambridge, MA) antibody at a concentration of $0.2 \mu \mathrm{g} /$ well, and incubated at $4{ }^{\circ} \mathrm{C}$ overnight. The wells were washed three times with PBST (phosphate saline containing 0.05\% Tween-20), and blocked with 3\% BSA in PBS for 2 hours at room temperature. After washing three times with PBST, $1 \mu \mathrm{g}$ of extracted total algal protein was added per well, and plates incubated overnight at $4^{\circ} \mathrm{C}$. After washing with PBST, 0.2 $\mu \mathrm{g}$ of rabbit anti-GAD65 (Serotec, Hornby, Canada) was added per well and incubated at room temperature for 2 hours. After washing, $50 \mu \mathrm{L}$ of 1:2000 diluted HRP-conju- 


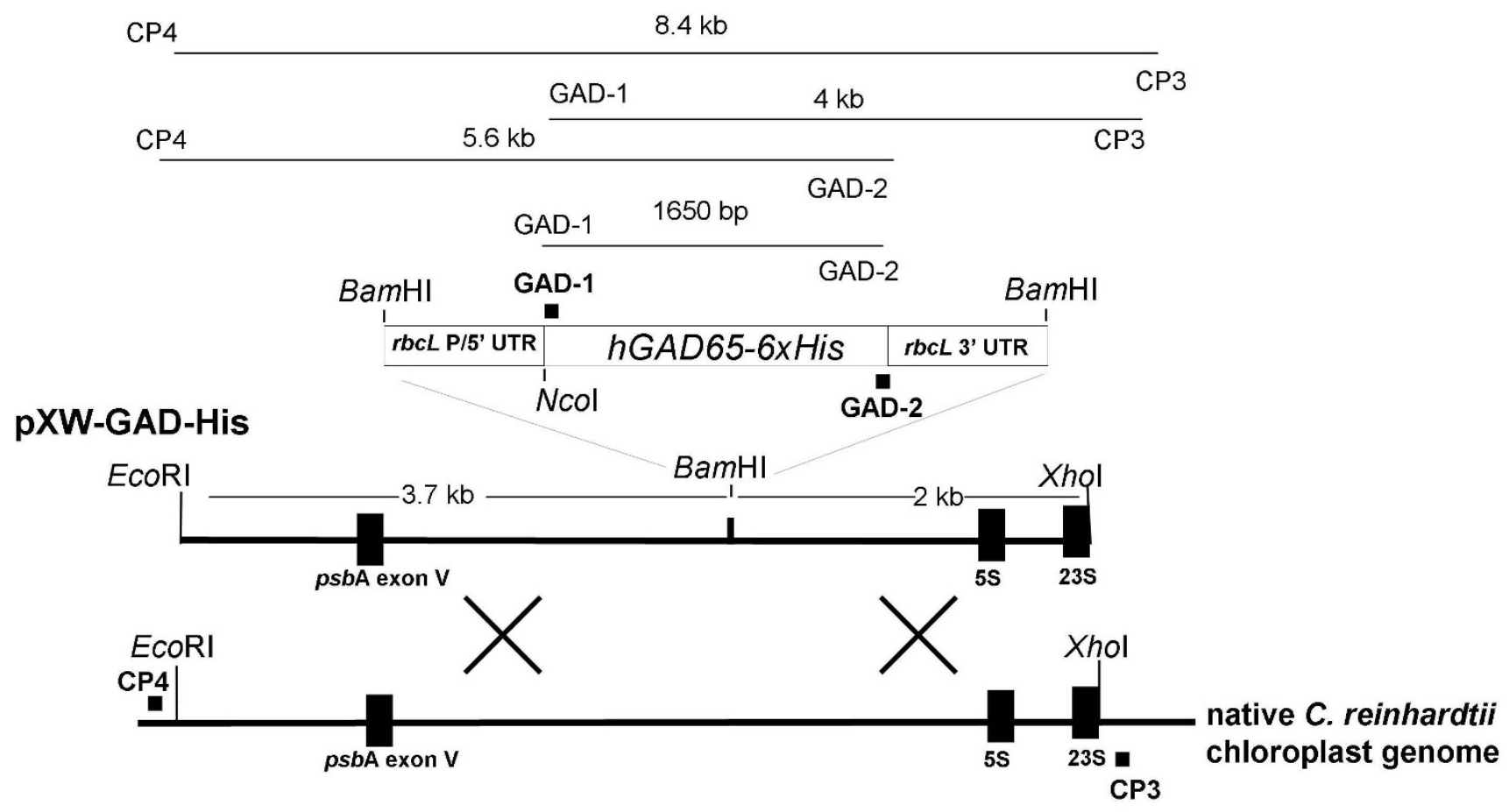

\section{Figure I}

Schematic diagram of the $h$ GAD65 chloroplast expression vector $\mathrm{pXW}$-GAD-His and the site of integration of the transgene cassette into the chloroplast genome. The $h G A D 65$ expression cassette consists of the $C$. reinhardtii chloroplast $r b c L$ promoter and 5'UTR upstream of the transgene followed by the rbcL 3'UTR. The transgene cassette was inserted into plasmid vector $\mathrm{p} 322$ that contains a cloned $5.7 \mathrm{~kb}$ (EcoRI/Xhol fragment) inverted repeat of $C$. reinhardtii chloroplast DNA, resulting in PXW-GAD-His. The restriction sites used for cloning are indicated. Primers GAD-I/GAD-2 corresponding to the $5^{\prime}$ and $3^{\prime}$ ends of $h G A D 65$ were used for PCR analysis to confirm the presence of the transgene in transformants, with the expected product size indicated. Primers CP3/CP4 complementary to sequences lying just outside the inverted repeat region of the $C$. reinhardtii chloroplast DNA were used to determine the site-specific integration of the transgene cassette into the $C$. reinhardtii chloroplast genome by PCR. The site-specific integration of the transgene cassette was additionally determined by PCR using GAD-I/CP3 and CP4/GAD-2 primer pairs. The regions for homologous recombination are indicated by the crosses. Selection of $C$. reinhardtii transformants was based on resistance to spectinomycin that was provided by co-transformation with plasmid p228 that contains the $16 \mathrm{~S}$ rRNA gene conferring spectinomycin resistance [38].

gated anti-rabbit IgG antibody (Kirkegaard \& Perry Laboratories, Gaithersburg, USA) was added per well and incubated at $37^{\circ} \mathrm{C}$ for 1 hour. After incubation, $100 \mu \mathrm{L} /$ well of TMB substrate (R\&D Systems, Minneapolis, MN) was added and incubated at $37^{\circ} \mathrm{C}$ for 15 minutes for color development. The color reaction was stopped by addition of $100 \mu \mathrm{L} /$ well stop solution (R\&D Systems, Minneapolis, $\mathrm{MN}$ ). The plate was read in a microplate reader (Bio-Rad $3550)$ at $450 \mathrm{~nm}$. The hGAD 65 concentration in samples was determined by comparison to a standard curve created with purified hGAD65 standard (Diamyd Diagnostics, Sweden).

\section{Purification of algal-derived hGAD65 protein}

Algal-derived recombinant hGAD65 was purified by histidine affinity chromatography using HiTrap Chelating HP columns (GE Healthcare) according to the manufacturer's instructions. In brief, a total of $100 \mathrm{ml}$ of C. reinhardtii cells were homogenized in $1 \mathrm{ml}$ extraction buffer (750 $\mathrm{mM}$ Tris-HCl, $\mathrm{pH} 8.0 ; 15 \%$ sucrose; $100 \mathrm{mM} \beta$-mercaptoenthanol; $1 \mathrm{mM}$ PMSF). The homogenate was centrifuged at $13,000 \times \mathrm{g}$ for $20 \mathrm{~min}$ at $4{ }^{\circ} \mathrm{C}$. The supernatant was filtered through a $0.45 \mu \mathrm{m}$ membrane filter, and loaded onto a HiTrap Chelating HP column and washed with wash buffer $\left(10 \mathrm{mM}\right.$ imidazol, $20 \mathrm{mM} \mathrm{Na} \mathrm{HPO}_{4}$, $500 \mathrm{mM} \mathrm{NaCl}$ ) to remove nonspecifically bound endogenous algal proteins. The bound algal-derived hGAD65 was eluted with elution buffer ( $500 \mathrm{mM}$ imidazol, $20 \mathrm{mM}$ $\mathrm{Na}_{2} \mathrm{HPO}_{4}, 500 \mathrm{mM} \mathrm{NaCl}$ ). Fractions were collected and analysed by SDS-PAGE and ELISA. The hGAD65 fraction was then dialyzed extensively against PBS to remove high salt and imidazolel, and concentrated using a speed vacuum. 


\section{Determination of immunoreactivity of algal-derived hGAD65 with diabetic sera by ELISA}

The antigenicity of algal-derived hGAD65 was determined by its immunoreactivity with diabetic sera from NOD mice using ELISA. In brief, purified algal-derived recombinant hGAD65 was added to a 96-well microtiter plate in a volume of $50 \mu \mathrm{l} /$ well $(10 \mu \mathrm{g}$ GAD $65 / \mathrm{ml}$ diluted in $0.1 \mathrm{M}$ $\mathrm{NaHCO}_{3}, \mathrm{pH} 8.5$ ) and incubated overnight at $4^{\circ} \mathrm{C}$. After incubation, the plate was washed, blocked with 3\% BSA in PBS solution, and incubated overnight at $4^{\circ} \mathrm{C}$ with diabetic and control serum samples ( $50 \mu \mathrm{l} /$ well in triplicate). Diabetic serum samples were obtained from newly-onset diabetic NOD mice, whereas control serum samples were collected from BALB/c mice. After washing, $50 \mu \mathrm{L}$ of 1:2000 diluted HRP-conjugated anti-mouse IgG antibody was added per well and the plate incubated at $37^{\circ} \mathrm{C}$ for 2 hours. The color development was performed as described above for sandwich ELISA.

\section{Spleen cell proliferation assay}

For the spleen cell proliferation assay, spleen cell suspensions were prepared from 8-week-old NOD mice. In brief, individual spleens were pressed through a sterile Falcon cell strainer (Becton Dickinson, Franklin Lakes, NJ), and lysed with ammonium chloride potassium (ACK) lysis buffer (Gibco/BRL, Rockville, MD) to remove erythrocytes. The resulting cell suspension was washed with DPBS (Dulbecco's phosphate buffered saline, SigmaAldrich Canada, Oakville, Ontario), and resuspended in complete RPMI 1640 media at a viable cell concentration of $5 \times 10^{5} \mathrm{ml}^{-1}$. Spleen cells were plated in triplicate in 96well flat-bottom microtitre plates $(100 \mu \mathrm{l} /$ well $)$, with insect cell-derived hGAD65 standard (Diamyd Diagnostics, Sweden), algal-derived hGAD 65 or the unrelated protein antigen ovalbumin (OVA) $(100 \mu \mathrm{l} /$ well of $10 \mu \mathrm{g} / \mathrm{ml}$ hGAD 65 or OVA) added. The cell cultures were incubated at $37^{\circ} \mathrm{C}$ in a $5 \% \mathrm{CO}_{2}$-humidified incubator for 72 hours and pulsed with $1 \mu \mathrm{Ci} /$ well tritiated thymidine. After a 16 hour post growth, cells were harvested, and the tritiated thymidine incorporated was determined by using a Beckman LS 6500 liquid scintillation counter (Beckman Coulter, Fullerton, Califonia). Results were shown as the mean counts per minute (CPM) of triplicate spleen-cell cultures.

\section{Results \\ Construction of a chloroplast expression vector and algal transformation}

The plasmid pXW-GAD-His (Figure 1) was constructed and used for C. reinhardtii chloroplast transformation. The expression of hGAD65 was under the control of the $C$. reinhardtii chloroplast $r b c \mathrm{~L}$ promoter and 5' UTR and 3' UTR. A C-terminal $6 \times$ His tag was added to facilitate purification of the recombinant protein using metal-affinity chromatography. The chimeric gene was flanked by sequence from an inverted repeat region of the C. rein- hardtii chloroplast genome to provide sites for in vivo homologous recombination. The plasmid pXW-GAD-His was transformed into wild-type $C$. reinhardtii chloroplasts by particle bombardment along with the plasmid p228 conferring spectinomycin resistance as a means of selection.

\section{PCR analysis of C. reinhardtii transformants}

C. reinhardtii transformants were selected on TAP agar plates supplemented with spectinomycin (TAP-Spec). Primary putative transformants were initially screened by PCR for the presence of the $h G A D 65$ gene using GAD specific primers. As shown in Figure 2A, PCR amplification of the genomic DNA obtained from primary transformants resulted in the synthesis of a product with expected 1.65 $\mathrm{kb}$ size. No PCR products were produced from DNA isolated from wild-type C. reinhardtii. Positive transformants were administered additional rounds of selection in order to obtain homoplasmic cell lines in which all copies of the chloroplast genome contained the introduced chimeric $h$ GAD 65 gene. To demonstrate that the $h$ GAD 65 expression cassette was site-specifically integrated into the algal chloroplast genome, long PCR amplification of genomic DNA from selected transformants was performed using a combination of primer sets. As indicated in Figure 1, primers CP3 and CP4 were designed to be complementary to sequences lying just outside the inverted repeat region of the $C$. reinhardtii chloroplast, and therefore PCR amplification of genomic DNA from transformants with a CP3 and CP4 primer pair would give an expected $8.4 \mathrm{~kb}$ DNA product if the hGAD65 cassette was correctly inserted into the inverted region of the algal chloroplast genome. As shown in Figure 2B, a DNA fragment of expected size was produced after PCR amplification. In contrast, PCR amplification of genomic DNA from wild-type $C$. reinhardtii using the same CP3/CP4 primer pair produced a band of smaller molecular weight $(5.8 \mathrm{~kb})$, equivalent in size to the inverted repeat region of the algal chloroplast DNA lacking inserted foreign DNA. The apparent lack of amplification of any $5.8 \mathrm{~kb}$ product from the inverted repeat region of chloroplast DNA with transformants further implies that transformants are all homoplasmic. Additional long PCR was performed using a combination of GAD and chloroplast specific primers to show foreign DNA inserted to the chloroplast inverted region was indeed that of $h G A D 65$. The primer GAD- 1 was designed according to the N-terminal coding sequence of hGAD 65. When CP3 and GAD-1 were used as a primer pair, a $4-\mathrm{kb}$ PCR product spanning the full hGAD 65 coding sequence ( $1.65 \mathrm{~kb}$ ), 3 ' rbcL UTR (440 bp) and the XhoI-BamHI fragment $(2 \mathrm{~kb})$ of the flanking inverted repeat region would be expected. As shown in Figure 2C, a 4-kb DNA fragment was obtained with the use of this primer pair. Similarly, when GAD-2 (designed for the C-terminal coding sequence of hGAD65) and CP4 
A.

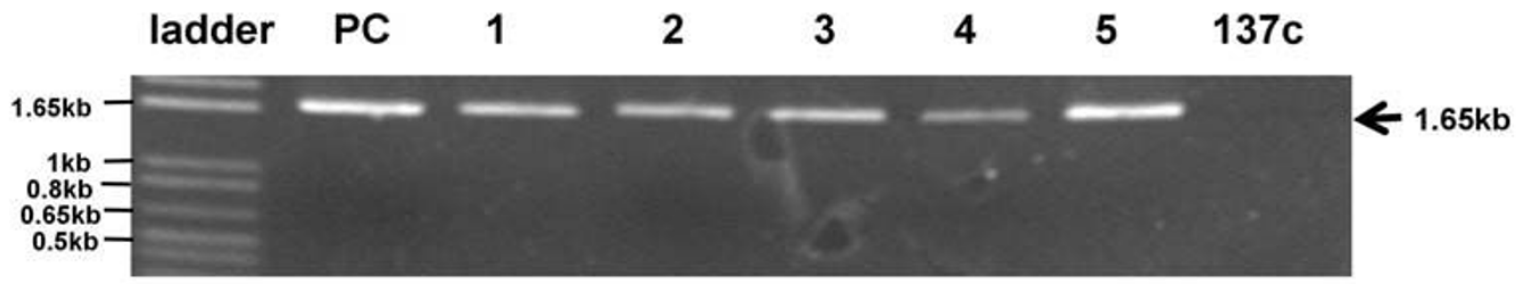

B.

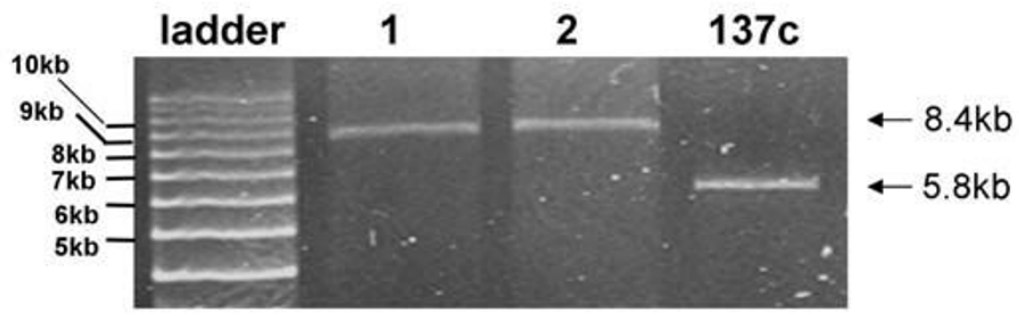

C.

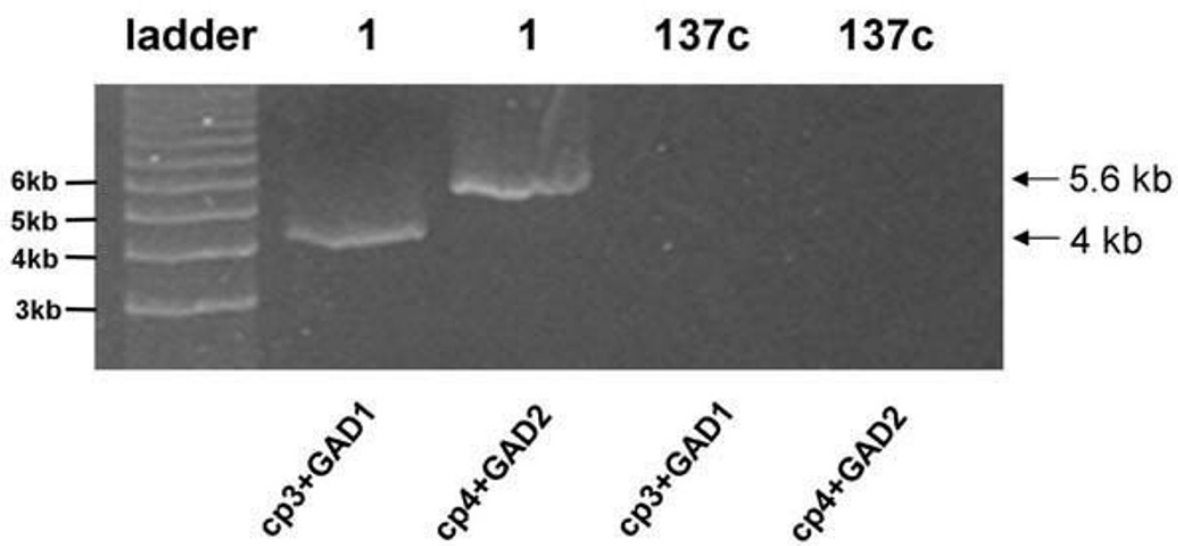

\section{Figure 2}

PCR analysis of $C$. reinhardtii transformants. (A) hGAD65 specific primers GAD-I and GAD-2 generated PCR products using total algal DNA as template. Lanes I to 5, independent $C$. reinhardtii transformants; PC, positive control (hGAD65 containing plasmid pXW-GAD-His). C. reinhardtii wild-type strain I37c DNA was used as a negative control. PCR products are indicated by the arrow. (B) Chloroplast specific primers CP3 and CP4 generated PCR products using total algal DNA as a template. Lanes I to 2, representative $C$. reinhardtii transformants; $C$. reinhardtii wild-type strain I37c DNA was used as a negative control. PCR products are indicated by the arrows. (C) The CP3/GAD-I or CP4/GAD-2 primer set generated PCR products. Lane I, representative $C$. reinhardtii transformant. $C$. reinhardtii wild-type strain I37c DNA was used as a negative control. PCR products are indicated by the arrows. 
were used as a primer pair, an expected 5.6-kb PCR product (corresponding to the full hGAD65 coding sequence (1.65 kb), chloroplast $r b c \mathrm{~L}$ promoter and 5' UTR (390 bp) and a $3.7-\mathrm{kb}$ BamHI-EcoRI fragment of the flanking inverted repeat region) was amplified from the same transformant (Figure 2C). As expected, no PCR products were generated from $C$. reinhardtii wild-type strain $137 \mathrm{C}$ DNA when the same CP3 and GAD-1 or CP4 and GAD-2 primer pair was used (Figure 2C). Taken together, these results suggest all transformants analysed were homoplasmic for the $h G A D 65$ cassette site-specifically inserted into the host chloroplast genome.

\section{Transcriptional analysis of hGAD65 in C. reinhardtii transformants by RT-PCR}

The transcriptional expression of $h G A D 65$ in C. reinhardtii transformants was evaluated by RT-PCR from total RNA isolated from wild-type $C$. reinhardtii and transformants. When $h$ GAD65 specific primers were used, a product of expected size $(1.65 \mathrm{~kb})$ was detected in cDNA reversetranscribed from RNA isolated from selected transformants (Figure 3). No RT-PCR products were detected in cDNA from wild-type C. reinhardtii. To rule out possible amplification of contaminant DNA in the samples, direct PCR amplification without reverse transcription was performed on the RNA preparations. No amplified PCR products were seen under the same conditions, confirming the specificity of the RT-PCR reaction (data not shown). In summary, these data indicate that hGAD65 is actively transcribed in chloroplast transformed algal cells.

\section{Accumulation of hGAD65 protein in C. reinhardtii transformants}

To demonstrate the accumulation of hGAD65 protein, total soluble protein (TSP) was prepared from wild-type
C. reinhardtii and transformants, and analyzed by Western blotting.

Anti-human GAD65 polyclonal antibody detected a single $65-\mathrm{kDa}$ band, corresponding in size to the hGAD65 protein (Figure 4). No protein band was detected in extracts from C. reinhardtii wild-type strain 137c. Accumulation levels of hGAD65 in algal cells were measured using ELISA. As shown in Figure 5, algal derived hGAD65 accounts for up to 0.25 to $0.3 \%$ of TSP.

\section{Immunoreactivity of algal-derived hGAD65 with sera from diabetic NOD mice}

Since prediabetic patients with type 1 diabetes and NOD mice contain anti-GAD antibodies in their sera [36], the antigenicity of algal-derived hGAD65 was determined by its immunoreactivity with diabetic sera. Thus, purified algal-derived hGAD65 was coated onto a microtiter plate and tested against three diabetic serum samples collected from NOD mice. Three serum samples obtained from $\mathrm{BALB} / \mathrm{c}$ mice were used as non-diabetic controls. As shown in Figure 6, all three diabetic serum samples had higher binding capacity to algal-derived hGAD65 than did reference serum samples, with samples number 2 and 3 showing a significant difference $(\mathrm{p}<0.05)$. These results suggest that algal-derived recombinant hGAD65 is antigenic.

\section{Effect of algal-derived hGAD65 on spleen cell proliferation} To further assess the antigenicity of algal-derived hGAD65, the effect of algal-derived hGAD65 on spleen cell proliferation was analyzed. Splenocytes were isolated from individual 8-week-old NOD mice and cultured with medium alone or stimulated with insect cell-derived hGAD65 standard, algal-derived hGAD65, or the irrelevant protein antigen ovalbumin (OVA). As shown in Fig-

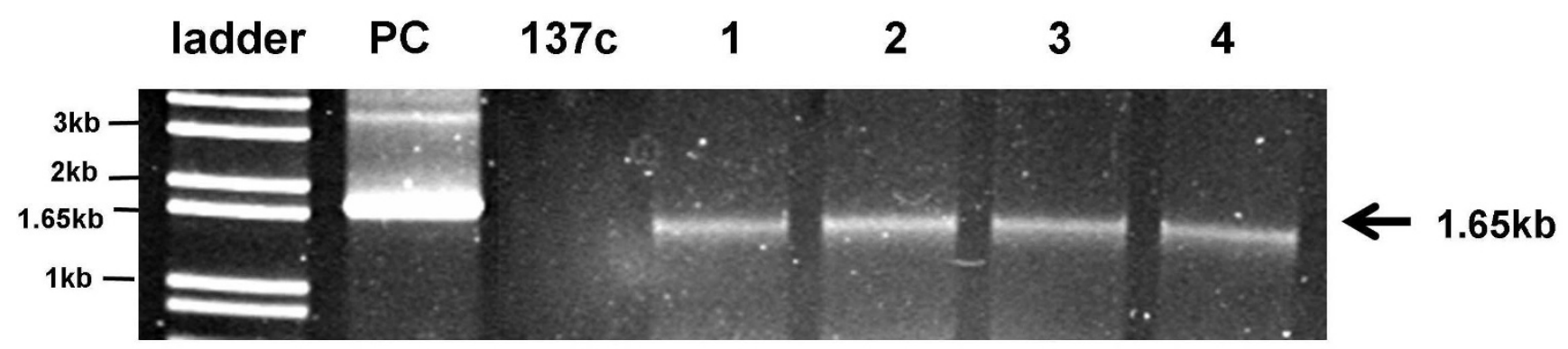

Figure 3

RT-PCR detection of hGAD65 mRNA expression in C. reinhardtii transformants. Total RNA was isolated from $C$. reinhardtii wild-type strain $137 \mathrm{c}$ and transformants. RNA was transcribed to cDNA as described in Methods. Resulting cDNA was amplified using primers specific to hGAD65. Lanes I to 4, PCR amplification of cDNA from independent transformants. PCR amplification of cDNA from wild-type strain I37c was used as a negative control. PC, positive control (direct PCR amplification of DNA from plasmid PXW-GAD-His). PCR products are indicated by the arrow. 


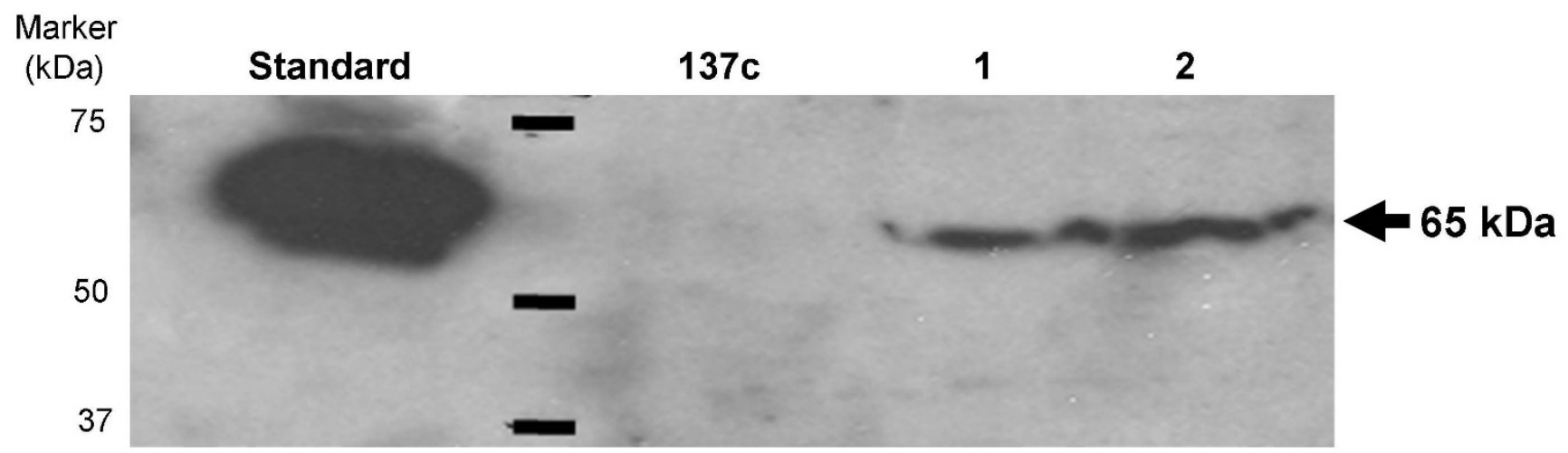

\section{Figure 4}

Western blot detection of recombinant hGAD65 from total soluble protein extracted from chloroplast transgenic algal lines. Samples containing $~ 50 \mathrm{ng}$ of commercial hGAD65 or $5 \mu \mathrm{g}$ of total algal protein were separated by I5\% sodium dodecylsulphate-polyacrylamide gel electrophoresis (SDS-PAGE), transferred onto a polyvinylidene difluoride membrane and probed with rabbit anti-GAD65 primary antibody followed by horseradish peroxidase conjugated goat anti-rabbit secondary antibody. Standard, insect cell-derived hGAD65. Lanes I to 2, protein extracts from two representative algal transformants. Protein extracts from wild-type strain 137c were used as a negative control. Arrows indicate the position of algalderived hGAD65.

ure 7, NOD mouse-derived spleen cells proliferated significantly in response to in vitro stimulation with algalderived hGAD65, with a magnitude of response compara- ble to the insect cell-derived hGAD65 standard. In contrast, NOD mouse-derived spleen cells cultured with medium alone or stimulated with OVA showed no signif-

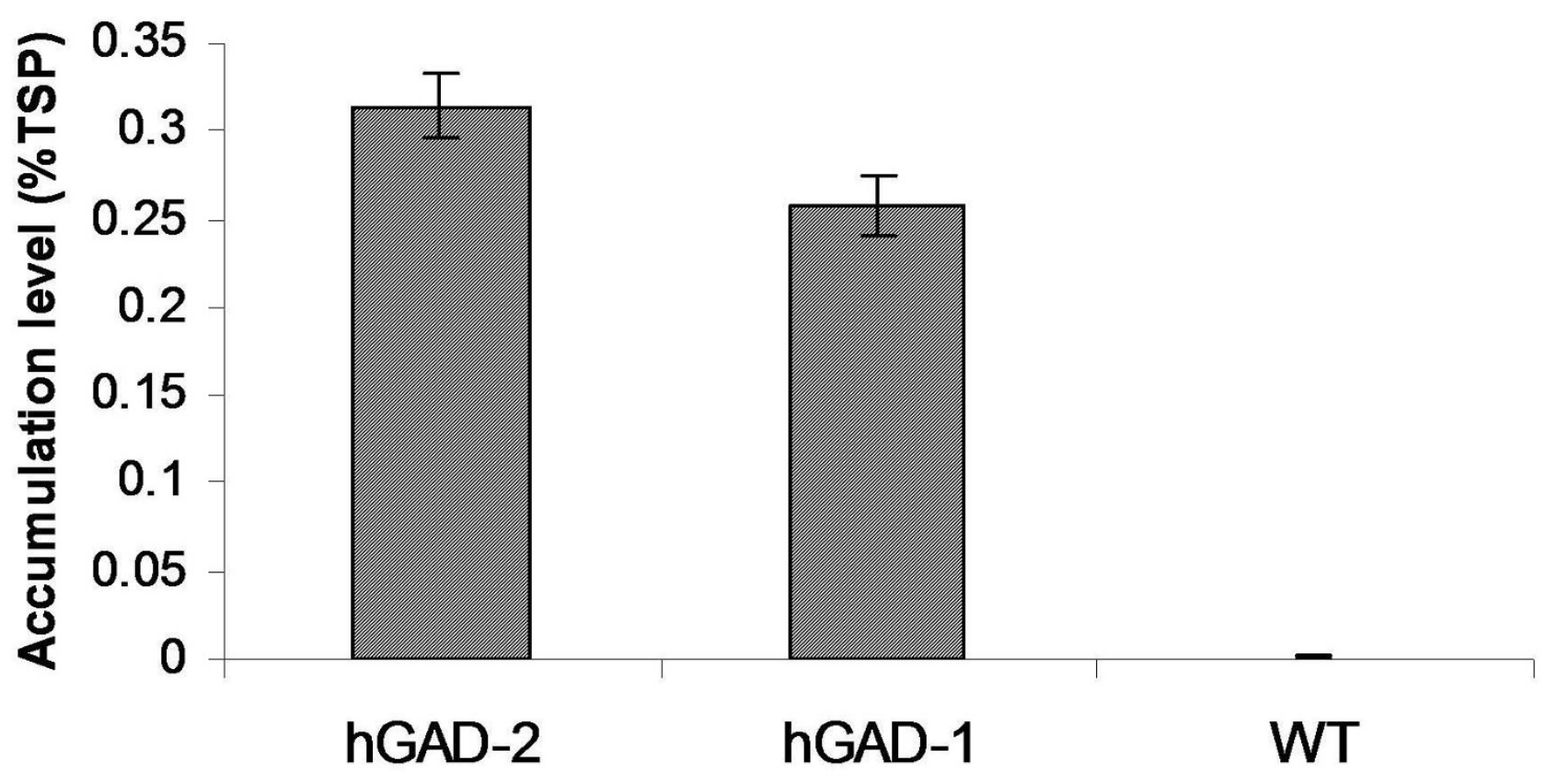

Figure 5

Expression levels as percentages of hGAD65 in total soluble protein (TSP) of hGAD65 expressing $C$. reinhardtii transformants. The expression level was determined by hGAD65 specific ELISA as described in detail in methods. hGAD-I and hGAD-2, two independent algal transformants; WT, untransformed wild type $C$. reinhardtii I37c strain. 


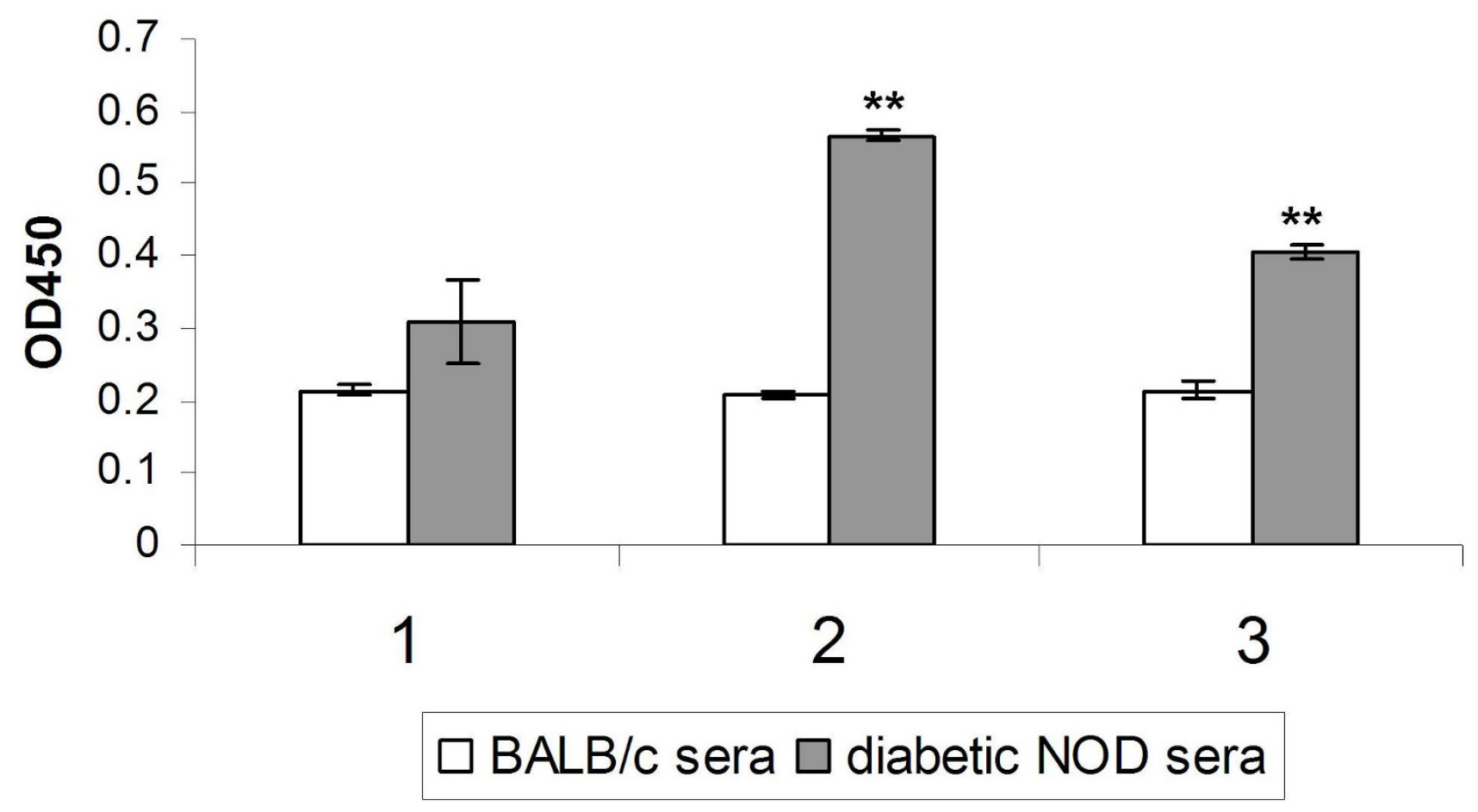

Figure 6

Demonstration of immunoreactivity with NOD mouse diabetic sera to algal-derived hGAD65. Purified algalderived hGAD65 was coated onto 96-well plates and incubated with serum samples from diabetic NOD mice $(n=3)$ and reference BALB/c mice $(n=3)$. Bound anti-GAD antibody was detected with HRP-conjugated anti-mouse IgG. Error bars represent the standard deviation. ** above bars indicates a significant difference from reference BALB/c sera $(p<0.05)$.

icant proliferative activity. The difference in cell response to algal-derived hGAD65 and OVA is significant ( $\mathrm{p}<$ $0.05)$. These results provide additional evidence that algal-derived hGAD65 is indeed immunogenic.

\section{Discussion}

The production of recombinant hGAD65 has been achieved in a number of expression systems including insect cells and E. coli, but all have been limited by their efficiency. Only low levels of hGAD65 accumulation was obtained in baculovirus-infected SF9 insect cells [41]. Moreover, this expression platform is technically and economically demanding, and hence is expensive and difficult to scale-up for mass production. The expression of hGAD65 as a fusion protein has been demonstrated in $E$. coli [42], but results in accumulation of recombinant product in insoluble inclusion bodies, needing solubilization, renaturation as well as chemical or enzymatic procedures to separate the target protein from its fusion partners. These additional processes can be expensive and time consuming. Our recent demonstration that hGAD65 can be expressed in transgenic tobacco may alleviate some of the problems associated with conventional expression platforms for hGAD65 production [37]. However, plant genomic expression of hGAD65 is still limited by low accumulation levels $(0.04 \%$ of TSP). Here we report the use of algal chloroplasts as a new type of bioreactor for the production of hGAD65. C. reinhardtii transformed with the $h G A D 65$ gene under control of the chloroplast $r b c \mathrm{~L}$ promoter and 5'-UTR was produced. The site-specific integration of the transgene into the chloroplast genome of $C$. reinhardtii was demonstrated by PCR (Figure 2). RT-PCR analysis revealed viable expression of $h$ GAD 65 mRNA in C. reinhardtii transformants (Figure 3 ). The accumulation of recombinant hGAD65 protein was further confirmed by Western blotting using anti-GAD antibody (Figure 4). As measured by ELISA, C. reinhardtii derived hGAD 65 protein accounted for up to 0.25 to $0.3 \%$ of total algal soluble protein (TSP) (Figure 5). This value is much higher when compared to hGAD65 expression in nuclear transgenic plants $(0.04 \%$ TSP) [37]. With a significant increase in immunologically active hGAD65 accumulation, taken together with $C$. reinhardtii's rapid growth rate, it is obvious that microalgae represent a superior platform for hGAD 65 production. In addition, algae are one of the easiest living organisms to propagate, requiring only sun- 


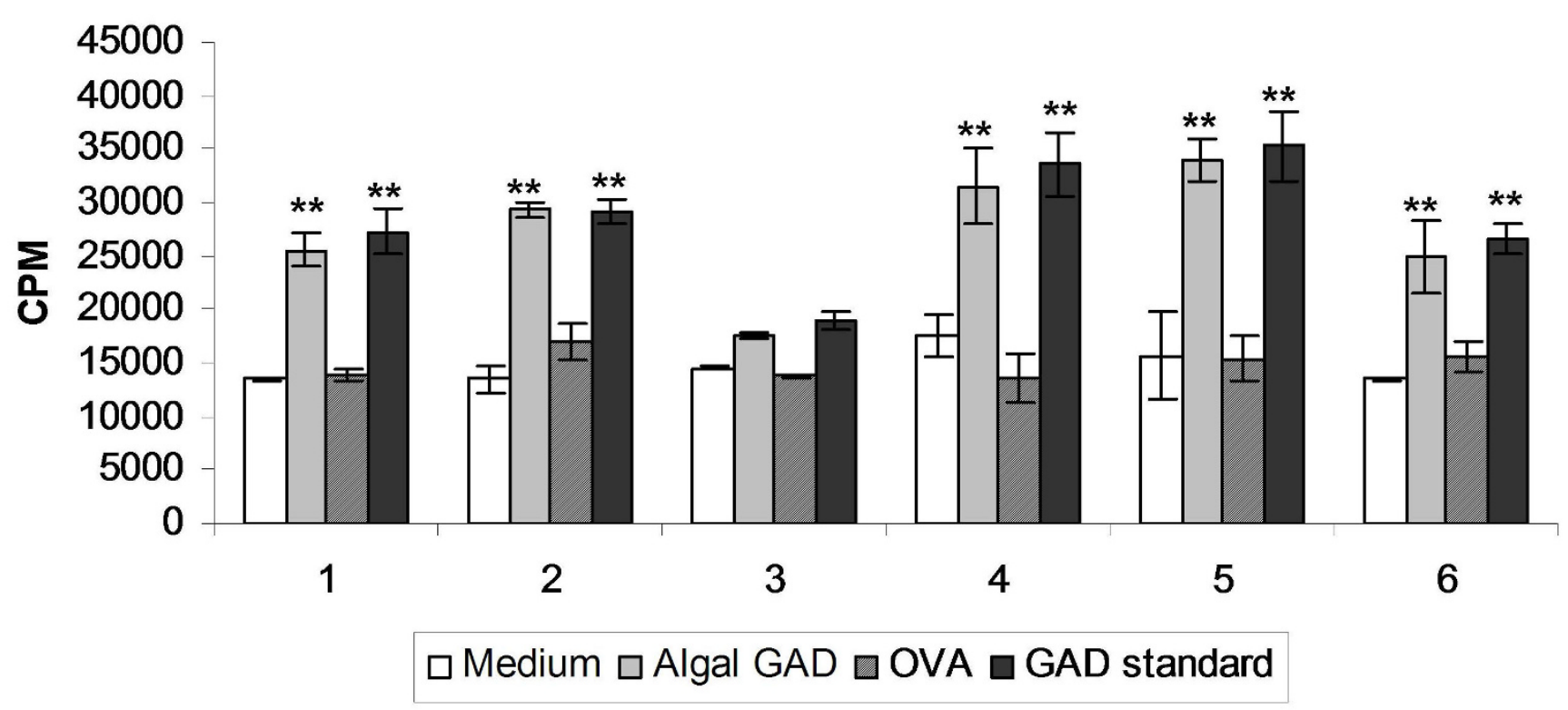

\section{Figure 7}

Spleen cell proliferation responses to algal-derived hGAD65. Individual 8-week-old NOD mice were tested for spontaneous proliferation of splenocytes to insect cell-derived hGAD65 standard, algal-derived hGAD65 or to the unrelated protein antigen ovalbumin (OVA). Error bars represent the standard deviation. ** above bars indicates a significant difference from OVA and medium alone $(p<0.05)$.

light, carbon dioxyde and water to thrive. It can be easily grown to industrial levels at very low cost. There are several common methods that can be used to grow algae at large scale, including the use of ponds, cheap flexible plastic bags or a solar photoreactor. As only the unmodified native form of hGAD65 gene under control of the chloroplast $r b c \mathrm{~L}$ gene promoter and its 5'-UTR was investigated in this pilot study, it is expected accumulation levels of hGAD65 in algal cells could be improved further if a $C$. reinhardtii chloroplast codon-optimized version of hGAD65 gene is used. The native hGAD65 DNA contains relatively low AT content (52\%) and its expression may not be favored by an AT-rich $C$. reinhardtii chloroplast genome in which the overall AT content is 65.5\% [43]. Franklin et al. [44] showed an 80-fold increase in expression levels of GFP (green fluorescent protein) in C. reinhardtii chloroplasts when a synthetic GFP gene with increased AT content (66\% AT content in synthetic GFP in comparison to native GFP with $60 \%$ AT content) was used. Furthermore, as the 5'-UTR region of chloroplast mRNAs has a profound effect on the translational efficiency of $C$. reinhardtii chloroplast genes $[45,46]$, the use of different 5'-UTRs of chloroplast genes such as the 5'UTR of the plastid $p s b$ A gene (D1 protein of photosystem II), combined with a strong promoter, could serve as another approach to enhance hGAD65 expression in $C$. reinhardtii cells. One additional strategy to improve hGAD65 expression may be the use of different host strains of C. reinhardtii. Mayfield and Schultz [47] reported a much higher expression (10-fold increase) of the luciferase reporter gene in $C$. reinhardtii chloroplasts when it was expressed in a $C$. reinhardtii mutant strain that lacked the corresponding endogenous gene (ie, the $p s b \mathrm{~A}$ deficient strain cc744).

The antigenicity of algal-derived hGAD65 was demonstrated based on its immunoreactivity with diabetic sera as well as its ability to stimulate the in vitro proliferation of splenic $\mathrm{T}$ cells derived from NOD mice. Anti-GAD antibodies are present in $>70 \%$ of newly diagnosed type 1 diabetic patients and have been detected up to 7 years before clinical onset of the disease $[48,49]$. Measurement of antiGAD antibodies has been proposed as a better predictor for the future development of type 1 diabetes in people at high risk [50]. Anti-GAD antibodies are also present in the sera of a majority of NOD mice and can be detected at an early stage of the disease [33,34]. Our results indicate that algal-derived hGAD65 reacts specifically with diabetic sera (Figure 6), suggesting its authentic GAD antigenicity. The in vitro spleen cell proliferation assay provides further evidence that algal-derived hGAD65 is immunogenic (Figure 7). In this assay, spleens derived from 8-week-old NOD mice were used as a source of spleen cells. In NOD mice, spontaneous proliferative $\mathrm{T}$ cell responses to GAD65 is seen as early as 4 weeks of age, parallel to the onset of insulitis. Also, the proliferative response is ini- 
tially confined to limited regions on the GAD65 molecule and subsequently spreads intramolecularly to different regions of GAD65 and intermolecularly to other $\beta$ cell antigens such as insulin [51]. Kaufman et al. [34] showed that spleen cells from 8-week-old NOD mice proliferate in response to GAD peptides. This study shows that NOD mouse-derived spleen cells proliferate when stimulated with algal-derived hGAD65, and that the stimulatory activity of algal-derived hGAD65 is comparable to insect cell-derived hGAD65 standard. As expected, addition of an unrelated protein antigen (OVA) had little effect on the proliferation of NOD mouse-derived spleen cells. The proliferation of spleen cells from one mouse (mouse \#3) was not significantly altered by the stimulation with either algal-derived hGAD65 or insect cell-derived hGAD65 standard. This is most likely due to a lower frequency of GAD reactive $\mathrm{T}$ cells within the spleen of this mouse as compared to other NOD mice. This observation is supported by Kaufman et al. [34] who examined the in vitro proliferative responses of spleen cells from individual NOD mice to GAD stimulation and showed variations in their proliferative responses to GAD.

The previous work by Ruhlman et al. [18] has showed the expression of diabetes-associated autoantigen human proinsulin in plant chloroplasts. In the present work, we have demonstrated the usefulness of $C$. reinhardtii chloroplasts as another platform for the production of diabetesassociated autoantigen hGAD65. To our knowledge, this is the first report on the use of algal chloroplasts for the production of a human autoantigenic protein. This demonstration opens the way for future use of $C$. reinhardtii chloroplasts as bioreactors for the production of other therapeutic proteins.

\section{Conclusion}

Currently there are no efficient expression systems available for recombinant production of hGAD65. In the present study, we have demonstrated that transplastomic C. reinhardtii is a superior expression platform for the production of hGAD65. This is the first report on the use of C. reinhardtii chloroplasts for the production of a fulllength autoantigenic protein. The ability to produce lowcost hGAD65 in large quantities will facilitate the development of immunoassays useful for screening and monitoring large numbers of individuals for susceptibility to type 1 diabetes, and also for the treatment of patients with type 1 diabetes.

\section{Authors' contributions}

SM and NH conceived and led the project. XW constructed the vectors, and performed the C. reinhardtii chloroplast transformation, Western blotting analysis, algal hGAD65 protein purification and its functional assays. $\mathrm{MB}$ conducted transplastomic C. reinhardtii genomic DNA isolation, determined the integration of hGAD65 cassette into the chloroplast genome by PCR and analyzed the transcriptional expression of hGAD65 by RT-PCR. RT developed hGAD65 ELISA protocol and performed the assay to demonstrate the expression level of hGAD65 in C. reinhardtii. AMJ and DM participated in experimental design.

\section{Acknowledgements}

The authors would like to thank Dr. M. Raizada, Department of Plant Agriculture, University of Guelph for the use of his Biolistic PDS-1000/He instrument. This research was supported by the Natural Sciences and Engineering Research Council (NSERC).

\section{References}

I. Goddijn OJM, Pen J: Plants as bioreactors. Trends Biotechnol 1995, 13(9):379-387.

2. Boehm R: Bioproduction of therapeutic proteins in the 2 Ist centu ry and the role of plants and plant cells as production platforms. Ann N Y Acad Sci 2007, I I 02: I2I-134.

3. Ma SW, Tremblay R, Wang XF, Jevnikar AM: Plant-based pharmaceuticals and its application in oral tolerance. In Immune Tolerance Research Development Edited by: Pontell EB. New York: Nova Science Publishers; 2008:79-95.

4. Ma JK, Drake PM, Christou P: The production of recombinant pharmaceutical proteins in plants. Nat Rev Genet 2003, 4(I 0):794-805.

5. Thanavala Y, Yang YF, Lyons P, Mason HS, Arntzen C: Immunogenicity of transgenic plant-derived hepatitis $B$ surface antigen. Proc Natl Acad Sci USA 1995, 92(8):3358-336I.

6. Wang XG, Zhang GH, Liu CX, Zhang YH, Xiao CZ, Fang RX: Purified cholera toxin $B$ subunit from transgenic tobacco plants possesses authentic antigenicity. Biotechnol Bioeng 200I, 72(4):490-494.

7. Jani D, Singh NK, Bhattacharya S, Meena LS, Singh Y, Upadhyay SN, Sharma AK, Tyagi AK: Studies on the immunogenic potential of plant-expressed cholera toxin B subunit. Plant Cell Rep 2004, 22(7):47|-477.

8. Daniell H: Production of biopharmaceuticals and vaccines in plants via the chloroplast genome. Biotechnol J 2006, I(10): $107 \mid-1079$

9. Daniell H, Lee SB, Panchal T, Wiebe PO: Expression of the native cholera toxin B subunit gene and assembly as functional oligomers in transgenic tobacco chloroplasts. J Mol Biol 200I, 3II(5): $1001-1009$.

10. Farran I, Sanchez-Serrano JJ, Medina JF, Prieto J, Mingo-Castel AM: Targeted expression of human serum albumin to potato tubers. Transgenic Res 2002, I I (4):337-346.

II. Fernandez-San Millan A, Mingo-Castel A, Miller M, Daniell H: A chloroplast transgenic approach to hyper-express and purify Human Serum Albumin, a protein highly susceptible to proteolytic degradation. Plant Biotechnol J 2003, I(2):7I-79.

12. Watson J, Koya V, Leppla SH, Daniell H: Expression of Bacillus anthracis protective antigen in transgenic chloroplasts of tobacco, a non-food/feed crop. Vaccine 2004, 22(3 I32):4374-4384.

13. Koya V, Moayeri M, Leppla SH, Daniell H: Plant-based vaccine: mice immunized with chloroplast-derived anthrax protective antigen survive anthrax lethal toxin challenge. Infect Immun 2005, 73( I 2):8266-8274.

14. Tregoning JS, Nixon P, Kuroda H, Svab Z, Clare S, Bowe F, Fairweather N, Ytterberg J, van Wijk KJ, Dougan G, Maliga P: Expression of tetanus toxin Fragment $\mathrm{C}$ in tobacco chloroplasts. Nucleic Acids Res 2003, 3 I (4): I I 74-I I 79.

15. Hennig A, Bonfig K, Roitsch T, Warzecha H: Expression of the recombinant bacterial outer surface protein $A$ in tobacco chloroplasts leads to thylakoid localization and loss of photosynthesis. FEBS / 2007, 274(2I):5749-5758.

16. Arlen PA, Falconer R, Cherukumilli S, Cole A, Cole AM, Oishi KK, Daniell $\mathrm{H}$ : Field production and functional evaluation of chlo- 
roplast-derived interferon-alpha2b. Plant Biotechnol J 2007, 5(4):5II-525.

17. Leelavathis S, Reddy VS: Chloroplast expression of His-tagged GUS-fusions: a general strategy to overproduce and purify foreign proteins using transplastomic plants as bioreactors. Mol Breed 2003, I I(I):49-58.

18. Ruhlman T, Ahangari R, Devine A, Samsam M, Daniell H: Expression of cholera toxin B-proinsulin fusion protein in lettuce and tobacco chloroplasts - oral administration protects against development of insulitis in non-obese diabetic mice. Plant Biotechnol j 2007, 5(4):495-5 I0.

19. Verma D, Daniell H: Chloroplast vector systems for biotechnology applications. Plant Physiol 2007, I 45(4): I I 29- I I 43.

20. Kamarajugadda $\mathrm{S}$, Daniell $\mathrm{H}$ : Chloroplast-derived anthrax and other vaccine antigens: their immunogenic and immunoprotective properties. Expert Rev Vaccines 2006, 5(6):839-849.

21. Mayfield SP, Manuell AL, Chen S, Wu J, Tran M, Siefker D, Muto M, Marin-Navarro J: Chlamydomonas reinhardtii chloroplasts as protein factories. Curr Opin Biotechnol 2007, 18:126-133.

22. Mayfield SP, Franklin SE, Lerner RA: Expression and assembly of a fully active antibody in algae. Proc Natl Acad Sci USA 2003, I00(2):438-442

23. Manuell AL, Beligni MV, Elder JH, Siefker DT, Tran M, Weber A, McDonald TL, Mayfield SP: Robust expression of a bioactive mammalian protein in Chlamydomonas chloroplast. Plant Biotechnol J 2007, 5(3):402-4I2

24. Sun M, Qian K, Su N, Chang H, Liu J, Shen G: Foot-and-mouth disease virus VPI protein fused with cholera toxin B subunit expressed in Chlamydomonas reinhardtii chloroplast. Biotechnol Lett 2003, 25(13): 1087-1092.

25. Yang Z, Li Y, Chen F, Li D, Zhang Z, Liu Y, Zheng D, Wang Y, Shen G: Expression of human soluble TRAIL in Chlamydomonas reinhardtii chloroplast. Chinese Science Bulletin 2006, 5I(I4):I703-I709.

26. He DM, Qian KX, Shen GF, Zhang ZF, Li YN, Su ZL, Shao HB: Recombination and expression of classical swine fever virus (CSFV) structural protein E2 gene in Chlamydomonas reinhardtii chroloplasts. Colloids Surf B Biointerfaces 2007, 55(I):26-30.

27. Franklin SE, Mayfield SP: Recent developments in the production of human therapeutic proteins in eukaryotic algae. Expert Opin Biol Ther 2005, 5(2):225-235.

28. Atkinson MA, Maclaren NK: The pathogenesis of insulindependent diabetes mellitus. N Engl J Med 1994 33 I(2I): I 428-1436

29. Atkinson MA, Eisenbarth GS: Type I diabetes: new perspectives on disease pathogenesis and treatment. Lancet 200I, 358(9277):22I-229.

30. Atkinson MA, Maclaren NK, Scharp DW, Lacy PE, Riley W]: 64,000 Mr autoantibodies as predictors of insulin-dependent diabetes. Lancet 1990, 335(8702): I357-1360.

31. Ellis TM, Atkinson MA: The clinical significance of an autoimmune response against glutamic acid decarboxylase. Nat Med 1996, 2(2): 148-153.

32. Sabbah E, Kulmala P, Veijola R, Vahasalo P, Karjalainen J, TuomilehtoWolf E, Akerblom HK, Knip M: Glutamic acid decarboxylase antibodies in relation to other autoantibodies and genetic risk markers in children with newly diagnosed insulindependent diabetes. Childhood Diabetes in Finland Study Group. I Clin Endocrinol Metab 1996, 8 I (7):2455-2459.

33. Tisch R, Yang XD, Singer SM, Liblau RS, Fugger L, McDevitt HO: Immune response to glutamic acid decarboxylase correlates with insulitis in non-obese diabetic mice. Nature 1993, 366(6450):72-75

34. Kaufman DL, Clare-Salzler M, Tian J, Forsthuber T, Ting GS, Robinson P, Atkinson MA, Sercarz EE, Tobin AJ, Lehmann PV: Spontaneous loss of T-cell tolerance to glutamic acid decarboxylase in murine insulin-dependent diabetes. Nature 1993 366(6450):69-72

35. Weiner HL: Oral tolerance: immune mechanisms and treatment of autoimmune diseases. Immunol Today 1997 18(7):335-343.

36. Yoon JW, Sherwin RS, Kwon H, Jun HS: Has GAD a central role in type I diabetes? J Autoimmun 2000, 15(3):273-278.

37. Ma S, Huang Y, Yin Z, Menassa R, Brandle JE, Jevnikar AM: Induction of oral tolerance to prevent diabetes with transgenic plants requires glutamic acid decarboxylase (GAD) and IL-4. Proc Natl Acad Sci USA 2004, I O I ( I5):5680-5685.

38. Boynton JE, Gillham NW, Harris EH, Hosler JP, Johnson AM, Jones AR, Randolph-Anderson BL, Robertson D, Klein TM, Shark KB: Chloroplast transformation in Chlamydomonas with high velocity microprojectiles. Science 1988, 240(4858): I534-I538.

39. Newman SM, Boynton JE, Gillham NW, Randolph-Anderson BL, Johnson AM, Harris EH: Transformation of chloroplast ribosomal RNA genes in Chlamydomonas: molecular and genetic characterization of integration events. Genetics 1990, I 26(4):875-888.

40. Goldschmidt-Clermont M: Transgenic expression of aminoglycoside adenine transferase in the chloroplast: a selectable marker of site-directed transformation of chlamydomonas. Nucleic Acids Res 1991, 19(1 5):4083-4089.

4I. Mauch L, Seissler J, Haubruck H, Cook NJ, Abney CC, Berthold H, Wirbelauer C, Liedvogel B, Scherbaum WA, Northemann W: Baculovirus-mediated expression of human $65 \mathrm{kDa}$ and $67 \mathrm{kDa}$ glutamic acid decarboxylases in SF9 insect cells and their relevance in diagnosis of insulin-dependent diabetes mellitus. Biochem 1993, II 3(6):699-704.

42. Papouchado ML, Valdez SN, Ghiringhelli D, Poskus E, Ermacora MR: Expression of properly folded human glutamate decarboxylase 65 as a fusion protein in Escherichia coli. Eur J Biochem 1997, 246(2):350-359.

43. Cambiaire JC, Otis C, Turmel M, Lemieux C: The chloroplast genome sequence of the green alga Leptosira terrestris: multiple losses of the inverted repeat and extensive genome rearrangements within the Trebouxiophyceae. BMC Genomics 2007, 8:2। 3-225.

44. Franklin S, Ngo B, Efuet E, Mayfield SP: Development of a GFP reporter gene for Chlamydomonas reinhardtii chloroplast. Plant J 2002, 30(6): 733-744.

45. Barnes D, Franklin S, Schultz J, Henry R, Brown E, Coragliotti A, Mayfield SP: Contribution of $5^{\prime}$ - and $3^{\prime}$-untranslated regions of plastid mRNAs to the expression of Chlamydomonas reinhardtii chloroplast genes. Mol Genet Genomics 2005, 274(6):625-636.

46. Kasai S, Yoshimura S, Ishikura K, Takaoka Y, Kobayashi K, Kato K, Shinmyo A: Effect of coding regions on chloroplast gene expression in Chlamydomonas reinhardtii. J Biosci Bioeng 2003, 95(3):276-282.

47. Mayfield SP, Schultz J: Development of a luciferase reporter gene, luxCt, for Chlamydomonas reinhardtii chloroplast. Plant / 2004, 37(3):449-458.

48. Rowley MJ, Mackay IR, Chen QY, Knowles WJ, Zimmet PZ: Antibodies to glutamic acid decarboxylase discriminate major types of diabetes mellitus. Diabetes I992, 4 I (4):548-55 I.

49. Pietropaolo M, Peakman M, Pietropaolo SL, Zanone MM, Foley TP Jr, Becker DJ, Trucco M: Combined analysis of GAD65 and ICA5 I 2(IA-2) autoantibodies in organ and non-organ-specific autoimmune diseases confers high specificity for insulindependent diabetes mellitus. J Autoimmun 1998, I I(I): I- I0.

50. Scriver C, Beaudet A, Sly W, Valle D: Type I Diabetes: An Autoimmune Disease. In The Metabolic and Molecular Bases of Inherited Disease Edited by: Scriver C, Beaudet A, Sly W, Valle D. New York: McGraw-Hill; 1995:859-863.

51. Quinn A: Antigen-induced TID in NOD mice. I Autoimmun 2003, 20(3):207-210. 